\title{
Chitinases of wheat seedling and their biochemical properties
}

\author{
Aidar Khakimzhanov, Vladimir Kuzovlev, Aset Abaildayev* \\ M.A. Aitkhozhin Institute of Molecular Biology and Biochemistry, Almaty, Kazakhstan
}

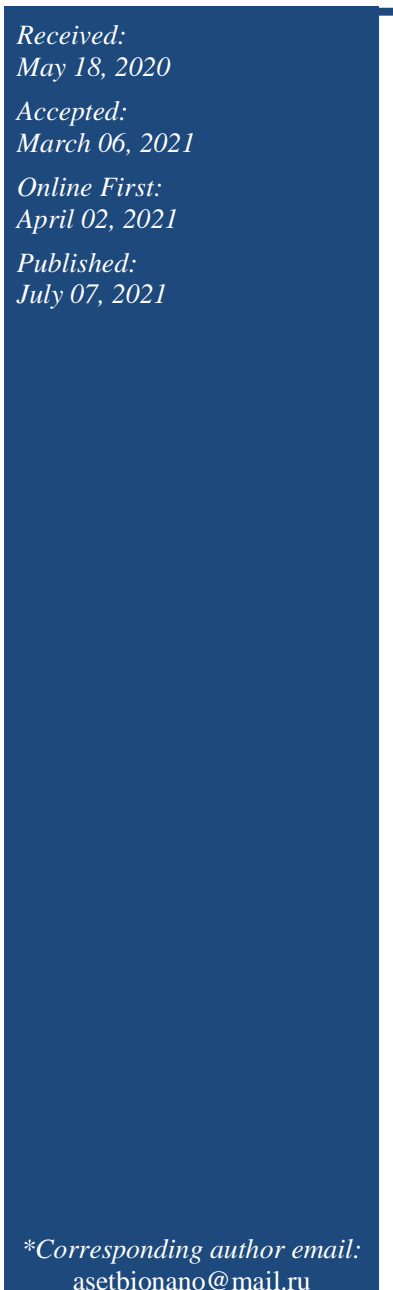

\section{Abstract}

Chitinases are important protective enzymes in plants and belong to a special group of pathogenesis-related (PR) proteins. The main target of these enzymes is various pathogenic fungi that contain chitin in their cell walls. Under the influence of fungi, chitinases produced by plants, hydrolyze chitin, which leads to suppression of the growth and death of the pathogen. Considering their important protective role, much attention is paid to the studies of these enzymes. Individual isozymes of chitinase are often used in testing and breeding agricultural plants for resistance to fungal diseases. In this work, we studied the isoenzyme composition and a number of physicochemical properties of wheat chitinases, which are important for a better understanding of their functioning in this grain crop. It was found that in seedlings of 7 days old, chitinases are localized both inside and outside the cells. Intracellular chitinase is represented only by basic components, whereas extracellular - by acidic ones. Using an affinity sorbent, the forms of the enzyme with a chitin-binding domain (CBD) were determined, which had isoelectric points (pI) of 9.3, 9.0, 8.6, 8.2, 8.0, 7.6, 5.7 and 4.6. According to SDSPAG electrophoresis, the molecular weight (M.w.) of these enzymes corresponded to the values of 33,35 and $56 \mathrm{kDa}$ and they were not the glycoproteins. In the spectrum of isoelectric focusing (IEF) of chitinases, exochitinases were identified, which had pI values exclusively in the acidic range of 4.3-5.2. Significant differences were revealed in the thermal stability of chitinases. The acidic components were most resistant to elevated temperatures.

Keywords: Triticum aestivum L., Seedling, Chitinase, Isoenzymes, Chitin-binding domain

\section{How to cite this:}

Khakimzhanov A, Kuzovlev V and Abaildayev A, 2021. Chitinases of wheat seedling and their biochemical properties. Asian J. Agric. Biol. 2021(3): 202005303. DOI: https://doi.org/10.35495/ajab.2020.05.303

This is an Open Access article distributed under the terms of the Creative Commons Attribution 3.0 License. (https://creativecommons.org/licenses/by/3.0), which permits unrestricted use, distribution, and reproduction in any medium, provided the original work is properly cited.

\section{Introduction}

Chitinolytic enzymes are widespread and are found in bacteria, fungi, plants and animals. In plants, chitinases are involved in some physiological processes - germination, embryogenesis, ethylene synthesis, digestion (carnivorous plants, that feed on insects), as well as in the fight against environmental stresses, that is, cold, drought, and salinity (Grover, 2012). Nevertheless, the main function of chitinases is to protect the plant organism from phytopathogens bacteria, fungi, nematodes and arthropods, the integuments of which contain chitin. Many of the chitinases have potentially high antifungal activity and are produced in response to a pathogenic attack (Kumar et al., 2018). The secreted enzymes hydrolyze 
the chitin of the cell walls to chitooligosaccharides and $\mathrm{N}$-acetylglucosamine. Due to the important protective and defense role, the study of plant chitinolytic enzymes has received much attention recently, as evidenced by a number of reviews (Sharma et al., 2011; Kumar et al., 2018; Iqbal and Anwar, 2019). Chitinases are part of the PR (pathogenesis-related) protein group and form 4 families out of 17 (PR-3, -4, -8 and -11) (Ebrahim et al., 2011; Sharma, 2013). Plant chitinase, like many polymer hydrolases, has multiple molecular forms and encoded by a family of genes. Additional difficulties in the study arise due to the presence of constitutive and inducible forms of the enzyme, as well as the tissue and organ specificity of their expression.

The significant polymorphism of chitinases is primarily due to the complex organization of natural substrates - chitin and its various derivatives of oligosaccharides, which suggests differences in the structure of enzymes, their substrate specificity, kinetic characteristics, and other properties (Kasprzewska, 2003; Kaczmarek et al., 2019). By the type of catalytic action, chitinases are divided into endochitinases (EC 3.2.1.14), which cleave internal bonds in chitin, forming chitotriose and chitobiose, and exochitinase - chitobiosidases (EC 3.2.1.29), cleaving off terminal diacetylchitobiose and $\mathrm{N}$-acetyl$\beta$-1,4-glucosaminidases (EC 3.2.1.30), which decompose the products of endo- and exochitinases to $\mathrm{N}$-acetylglucosamine. On the basis of the amino acid composition and structure of the catalytic center, chitinases were grouped into families of 18,19 , and 20 glycoside hydrolases (GH). Families 18 and 19 are considered to be chitinases, since they catalyze the degradation of chitinous polymers. Family 20 includes chitobiosidase and N-acetyl- $\beta$-1,4-glucosaminidase. Family 18 mainly consists of bacterial and fungal chitinases, while family 19 is represented exclusively by plant chitinases (Rathore and Gupta, 2015).

According to the primary structure, plant chitinases are divided into 7 classes (I-VII). Chitinases of classes III and V belong to the GH18 family, while chitinases of classes I, II, and IV belong to the GH19 family. In cereals, the first three classes of enzymes are most commonly found. It was shown that there is no definite correlation in the distribution of chitinases across plant species, their organs and tissues, but it was found that only some of them have antifungal properties (Taira, 2010; Oyeleye and Normi, 2018).

Class I chitinases are found only in plants and are induced in response to a pathogen. They have complete $\mathrm{N}$ - and C-terminal domains, during biosynthesis, most of them are directed to the vacuole (Gijzen et al., 2001; Taira et al., 2002). These chitinases are generally highly antifungal. In their structure, they contain a chitin-binding domain (CBD), due to which a strong antifungal effect is provided. Nearby is the spacer (hinge) region and the catalytic domain. Chitinases of this class are divided into 2 subclasses - I a (acidic forms) and II b (basic forms). Class II chitinases have been found not only in plants, but also in bacteria and fungi. They are structurally similar to class I chitinases, but lack CBD and spacer regions (Taira, 2010). Enzymes of this class have acidic properties. Class III chitinases have a unique structure and differ from all other chitinases. They are multifunctional and exhibit lysozyme, exochitinase activity and are similar to bacterial chitinase. There is no CBD in their structure. These enzymes have a wide range of optimum $\mathrm{pH}$ values and are thermostable at $60-70^{\circ} \mathrm{C}$. Chitinases of classes IV, $\mathrm{V}, \mathrm{VI}$, and VII are hardly found in cereals (Sharma et al., 2011).

To date, chitinases have been most studied in tobacco, and barley, rice, and rye among cereals. Wheat chitinase contains about 10 isoforms with a wide range of isoelectric points (pI) - in the range of acidic, basic and neutral $\mathrm{pH}$ from $\sim 3.1$ to 9.7 with a molecular weight of $\sim 20$ to $40 \mathrm{kDa}$ (Ride and Barber, 1990; Mohammadi et al., 2002 ; Moravč́́ková et al., 2017). This suggests differences in physicochemical properties and $\mathrm{pH}$ optimum of action, which is very important for display of activity in a pathogenic attack. Despite some success, the wheat chitinase complex remains poorly studied.

Kazakhstan is one of the major producers and exporters of wheat. In this regard, the country pays great attention to increasing the yield and resistance of this grain crop to phytopathogens. The article presents some new data on the composition and some physicochemical properties of wheat chitinases, which contribute to a better understanding of the functioning of these defense enzymes in this grain crop.

\section{Material and Methods}

\section{Plant materials}

Wheat grain, variety Shortandy 98 (T. aestivum L.), was obtained from A.I. Barayev Scientific and Production Center of grain farming, Shortandy, Kazakhstan. 


\section{Growing wheat seedlings}

$10 \mathrm{~g}$ of grain were soaked in distilled water for 1 hour, sterilized with $0.5 \%$ sodium hypochlorite for 5 minutes, washed with several portions of running water and rinsed with distilled water. The grains were planted on moistened filter paper in plastic containers with lids and germinated in a thermostat in the dark at $22^{\circ} \mathrm{C}$ for 7 days. The obtained seedlings were placed in a glassful and washed with distilled water. Grains, roots, and shoots were detached from the seedlings, which were used for preparation of the enzyme extracts.

\section{Preparation of the enzyme extract}

The plant material was homogenized in $0.05 \mathrm{M}$ sodium acetate buffer $\mathrm{pH} 5.0$ at a ratio of 1:3. The homogenate was infused at $4^{\circ} \mathrm{C}$ for 1 hour, then centrifuged at $10000 \mathrm{~g}$ for 15 minutes. The supernatant was used as a source of enzymes.

\section{Assay of chitinase activity}

The chitinase activity was assayed spectrophotometrically (Fink et al., 1988) with some modification. The reaction mixture contained $0.1 \mathrm{ml}$ of $5 \%$ colloidal chitin (Sigma) in $0.05 \mathrm{M}$ sodium acetate buffer $\mathrm{pH} 5.0,0.1 \mathrm{ml}$ of $0.5 \mathrm{M}$ sodium acetate buffer $\mathrm{pH} 5.0,0.7 \mathrm{ml}$ of distilled water, and $0.1 \mathrm{ml}$ enzyme extract. The mixture was incubated at $37^{\circ} \mathrm{C}$ for 5 hours, after which the reaction was stopped by adding $1 \mathrm{ml}$ of 3,5-dinitrosalicylic acid (DNS) reagent, followed by boiling at $90^{\circ} \mathrm{C}$ for 10 minutes. Then the mixture was cooled on ice for 5 minutes and centrifuged at $8000 \mathrm{~g}$ for 10 minutes. The absorbance of the samples was measured at a wavelength of 540 $\mathrm{nm}$ against a control prepared in the same way, but with the addition of DNS before adding the enzyme extract. The specific activity of chitinase was expressed in $\mathrm{mg} / \mathrm{ml}^{-1} \mathrm{~N}$-acetyl-D-glucosamine (NAG) per 1 hour $^{-1}$ per $1 \mathrm{mg}^{-1}$ protein. The chitinase activity of the samples was measured in triplicate, from which the average value was determined. The protein content in plant extracts was determined by the method (Lowry et al., 1951).

\section{Isolation of apoplastic and vacuolar chitinases}

Isolation of apoplastic fluid was performed from whole wheat shoots by infiltration-centrifugation method (O'Leary et al., 2014) with some modifications. Shoots of 7 days old seedlings were cut off at the base, washed three times with distilled water, and slightly dried on filter paper. Plant material in the amount of $8 \mathrm{~g}$ was soaked for 2 minutes in a solution of $0.05 \%$ Triton $\mathrm{X}-100$, washed with distilled water and dried. The seedlings were placed in a Bunsen flask with $150 \mathrm{ml}$ distilled water cooled to $4^{\circ} \mathrm{C}$ and containing $100 \mathrm{mM} \mathrm{KCl}$. The plant material was infiltrated at a pressure of 10 mbar for 30-40 minutes using a PC3001 Vario vacuum pump (Vacuubrand, Germany). As a result of this procedure, the shoots acquired a deep dark color, after which they were washed with distilled water and dried with filter paper. After that, the shoots were placed in $50 \mathrm{ml}$ test-tube and centrifuged at $4{ }^{\circ} \mathrm{C}$ for 15 minutes at a speed no exceeding $3000 \mathrm{~g}$. The liquid accumulated at the bottom of the test-tube contained extracellular apoplastic chitinase, whereas the plant extract contained an intracellular vacuolar enzyme. To isolate intracellular chitinase, infiltrated 7 days old shoots (8 g) without intercellular fluid were homogenized in 24 $\mathrm{ml}$ of $0.05 \mathrm{M}$ sodium acetate buffer, $\mathrm{pH}$ 5.0. The homogenate was incubated at $4^{\circ} \mathrm{C}$ for 1 hour and centrifuged at $8000 \mathrm{~g}$ for 15 minutes. The enzyme supernatant was dialyzed against $0.05 \mathrm{M}$ sodium acetate buffer $\mathrm{pH} 5.0$ at $4{ }^{\circ} \mathrm{C}$ and stored at $-20^{\circ} \mathrm{C}$ until use.

\section{Chitinase purification by substrate affinity chromatography}

At the first stage of chitinase purification, the supernatant proteins were precipitated with ammonium sulfate within the saturation range of 30$80 \%$ at $0^{\circ} \mathrm{C}$ for 1 hour. The protein precipitate was collected by centrifugation at $10000 \mathrm{~g}$ for 10 minutes at $4{ }^{\circ} \mathrm{C}$. The precipitate was dissolved in $4 \mathrm{ml}$ of 0.05 $\mathrm{M}$ sodium acetate buffer, $\mathrm{pH}$ 5.0, and centrifuged to remove insoluble impurities. The protein solution was desalted using a CentriPure P10 Column (Serva, Germany) with a volume of $1.5 \mathrm{ml}$ according to the manufacturer's protocol. All protein fractions were stored at $-20^{\circ} \mathrm{C}$ until use.

Chitinases with chitin binding domain (CBD) of shoots, roots, germinating and dormant wheat grains were purified by column chromatography on chitin resin (New England Biolabs, USA) according to the method described in (Sørensen et al., 2010). Chromatographic procedures were carried out at $8^{\circ} \mathrm{C}$ using a glass column of $0.8 \times 4 \mathrm{~cm}$. The chitin resin sorbent in $2 \mathrm{ml}$ of $0.05 \mathrm{M}$ sodium phosphate buffer, $\mathrm{pH} 7.4$ was placed in the column. The column was equilibrated with the same buffer. After precipitation with ammonium sulfate $0.5 \mathrm{ml}$ of a protein solution was dialyzed against $0.05 \mathrm{M}$ sodium phosphate buffer, 
pH 7.4 and loaded onto the column. The binding of chitinase to the affinity sorbent was carried out slowly over 40 minutes. Unbound proteins were removed first with starting buffer and then with $0.05 \mathrm{M}$ sodium acetate buffer $\mathrm{pH}$ 5.1. Protein fractions were collected by $0.5 \mathrm{ml}$. The proteins not bound to chitin were concentrated to a volume of $1.5 \mathrm{ml}$ in an Amicon cell (Millipor, USA) on a PM-10 filter. The bound enzyme was eluted with $20 \mathrm{mM}$ acetic acid, $\mathrm{pH}$ 3.0. The protein solution was neutralized to $\mathrm{pH} 6.5-7.0$ by adding $0.5 \mathrm{M}$ sodium phosphate buffer $\mathrm{pH} 7.4$ immediately after elution. Buffer was added dropwise to each fraction and the $\mathrm{pH}$ was monitored using indicator paper. Fractions containing chitinase were pooled and dialyzed against $0.05 \mathrm{M}$ sodium acetate buffer, $\mathrm{pH} 5.0$ on a CentriPure P10 column. The enzyme solution was concentrated to a volume of 1.5 $\mathrm{ml}$. The chitin resin column chromatography procedure was performed three times for each organ. Enzyme preparations were stored at $-20^{\circ} \mathrm{C}$ until use.

\section{Isoelectrofocusing (IEF) and chitinases detection in PAG}

Separation of chitinase isozymes was performed by native isoelectric focusing (IEF) technique using a Multiphor II horizontal electrophoresis chamber (GE Healthcare, Sweden). A polyacrylamide gel (PAG) with size $9 \times 12 \times 0,1 \mathrm{~cm}$ contained $5 \%$ acrylamide and $2 \%$ Servalyt pH 3.0-10.0 (Serva, Germany). Enzyme samples with a volume of $15 \mu \mathrm{L}$ were applied to the surface of the horizontal gel in the center using paper applicators $10 \times 5 \mathrm{~mm}$ in size (Serva, Germany). First, the IEF was carried out at a voltage of $100 \mathrm{~V}$ for 1 hour, then every hour the voltage was increased by 100 $\mathrm{V}$, bringing it to a final voltage of $500 \mathrm{~V}$. During the IEF, the gel was cooled at $6^{\circ} \mathrm{C}$.

Endochitinase isozymes were detected using a gel replica with copolymerized glycol chitin according to the method (Pan et al., 1989). Glycol chitin was obtained by the method (Molano et al., 1979). After IEF, the gel was incubated in $0.05 \mathrm{M}$ sodium acetate buffer $\mathrm{pH} 5.0$ for 10 minutes. Then a $5 \%$ polyacrylamide coating gel (replica) $1 \mathrm{~mm}$ thick containing $0.04 \%$ glycol chitin was applied to the separating gel. The overlaid sandwich gels were incubated at $37^{\circ} \mathrm{C}$ for 2 hours in a glass container under humid conditions. Then the replica was removed and placed in a freshly prepared $0.01 \%$ fluorescent bridgethener 28 (Sigma, USA) in $0.5 \mathrm{M}$ Tris- $\mathrm{HCl}$ buffer $\mathrm{pH} 8.9$ at $25^{\circ} \mathrm{C}$ for 15 minutes. The replica was incubated in distilled water at $+8^{\circ} \mathrm{C}$ for 24 hours. The bands of activity were visualized on a Quantum ST5 Gel Doc instrument (Vilber Lourmat, France) under UV light with a wavelength of $365 \mathrm{~nm}$. A kit of proteins (Sigma, USA) was used as markers of isoelectric points (pI): amyloglucosidase - 3.6; trypsin inhibitor - 4.6; $\beta$-lactoglobulin -5.1; carbonic anhydrase 5.9, 6.6; myoglobin - 6.8, 7.2; lectin - 8.2, 8.6, 8.8; trypsinogen - 9.3.

Exochitinase isozymes ( $\mathrm{N}$-acetylglucosaminidase) were detected in PAG according to the method (Dušková et al., 2011) with some modifications. After IEF, the gel was incubated in $0.05 \mathrm{M}$ sodium acetate buffer $\mathrm{pH} 5.0$ for 10 minutes at $37^{\circ} \mathrm{C}$. Filter paper impregnated with the chromogenic substrate 4methylumbelliferyl-N-acetyl- $\beta$-D-glucosaminide (4MUF-NAG) (Sigma, USA) at a concentration of $0.02 \%$ was applied to the separating gel. The gel was incubated at $37^{\circ} \mathrm{C}$ for $30-40$ minutes in a closed glass container under humid conditions. The zones of activity were visualized on a Quantum ST5 Gel Doc instrument (Vilber Lourmat, France) under UV light with a wavelength of $365 \mathrm{~nm}$.

\section{Sodium dodecyl-sulfate (SDS) PAG electrophoresis of proteins}

The electrophoretic separation of proteins was carried out in an $8 \times 8,5 \times 0,1 \mathrm{~cm}$ plate with $12 \%$ separating and $5 \%$ concentrating PAG with sodium dodecyl-sulfate according to the method (Laemmli, 1970) using a Compact Dual Mini TV-100Y vertical electrophoresis chamber (England). Protein extracts of $20 \mu$ were mixed with $20 \mu 1$ Sample Buffer 2X (Serva, Germany) and boiled at $95^{\circ} \mathrm{C}$ for 5 minutes. Electrophoresis was carried out for 30 minutes at a voltage of $40 \mathrm{~V}$, and then for 2 hours at a voltage of $150 \mathrm{~V}$. To staining total protein, the gel was fixed for $1 \mathrm{~h}$ in $20 \%$ trichloroacetic acid at room temperature. The gel was stained for 2 hours at $37^{\circ} \mathrm{C}$ with $0.1 \%$ Coomassie Brilliant Blue R250 solution (Sigma, USA) freshly prepared in 7\% acetic acid and $20 \%$ ethanol. Excess dye in the gel was removed by repeated washing in $7 \%$ acetic acid. A kit of proteins (Pharmacia Biotech, Sweden) was used as molecular weight (M.w.) markers: $\alpha$-lactalbumin 14.4, trypsin inhibitor - 20.1, carbonic anhydrase 30.0, ovalbumin - 43.0, albumin - 67.0, and phosphorylase b - 94.0.

\section{Detection of chitinase activity after SDS-PAG electrophoresis}

Zones of chitinase activity after SDS-PAG electrophoresis were revealed according to the method 
(Trudel and Asselin, 1989). After electrophoresis, SDS was removed from the gel by incubation at $37^{\circ} \mathrm{C}$ in $0.05 \mathrm{M}$ sodium acetate buffer $\mathrm{pH} 5.0$ containing $1 \%$ Triton X-100 for $2 \mathrm{~h}$. The gel was re-soaked for 1 hour in $0.05 \mathrm{M}$ sodium acetate buffer $\mathrm{pH} 5.0$ at $25^{\circ} \mathrm{C}$ without Triton X-100. The gels were then incubated in freshly prepared $0.01 \%$ Fluorescent Bridgethener 28 in $0.5 \mathrm{M}$ Tris- $\mathrm{HCl} \mathrm{pH} 8.9$ at $25^{\circ} \mathrm{C}$ for 15 minutes. After that, the gels were left in distilled water at $8^{\circ} \mathrm{C}$ for 24 hours. Zones of enzyme activity were revealed in the same way as in the case of the IEF.

\section{Staining of glycoproteins after SDS-PAG electrophoresis}

Staining of glycoproteins after SDS-PAG electrophoresis was performed using a reagent kit (Pierce, no. 24562, USA). In short, the principle of the method consists in the oxidation of the carbohydrate residue of glycoproteins by periodate to aldehydes, followed by staining of glycols with Schiff reagent. The preparation of working reagents and the procedure for staining glycoproteins were carried out according to the instructions attached to the kit. After electrophoresis, the gel was immersed in $100 \mathrm{ml}$ of $50 \%$ ethanol and fixed for 30 minutes. The gel was transferred into $100 \mathrm{ml}$ of $3 \%$ acetic acid, then washed with gentle stirring for 10 minutes. We repeated this step once again. The gel was transferred into $25 \mathrm{ml}$ of an oxidizing solution and stirred gently for 15 minutes. The gel was washed by gently shaking in $100 \mathrm{ml}$ of $3 \%$ acetic acid for 5 minutes. This step was repeated two more times. The gel was transferred into $25 \mathrm{ml}$ of glycoprotein dye and mixed gently for 15 minutes. The gel was then transferred into $25 \mathrm{ml}$ of a recovery solution and gently mixed for 5 minutes. The gel was thoroughly washed with $3 \%$ acetic acid and distilled water. The glycoproteins appeared as purple streaks. The gel was stored in 3\% acetic acid. After staining, the gel was photographed.

\section{Effect of temperature on chitinase activity}

Samples of the enzyme $(0.4 \mathrm{ml}$ each $)$ after precipitation with ammonium sulfate were heated at temperatures of 30 (control), 60, 63, 66 and $69^{\circ} \mathrm{C}$ for 10 minutes in a water bath, sharply cooled in ice water and centrifuged for 10 minutes at a speed of $8000 \mathrm{~g}$. The supernatant was collected and used for the analysis of the isozyme composition of chitinases by the IEF technique.

\section{Results}

Cellular localization and detection of endo- and exochitinases of wheat seedlings in the IEF spectrum

Chitinases differ in their localization, among which there are intracellular and extracellular forms. According to some data, intracellular (vacuolar) chitinase can quantitatively exceed the extracellular (apoplastic) enzyme by several times. Moreover, in some plants, apoplastic chitinase is hardly found in the norm. The accumulation of the enzyme in the intercellular fluid was observed under external influences, in particular, during fungal pathogenesis (Anand et al., 2004; Aleandri et al., 2008). These features of cell localization and quantitative distribution suggest differences in the defense functions of chitinase.

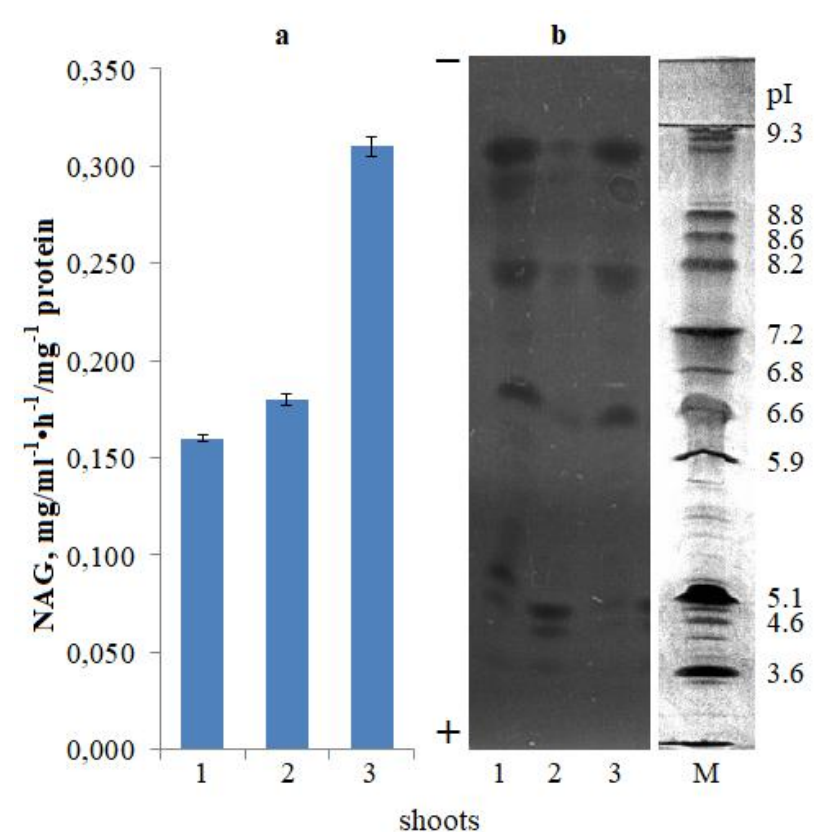

Figure-1. Activity (a) and IEF (b) of chitinase of the wheat shoots: 1- total chitinase, 2- extracellular (apoplastic) chitinase, 3- intracellular (vacuolar) chitinase, M- pI markers

In our studies, the levels of extracellular (apoplastic) and intracellular (vacuolar) chitinase activity of shoots of 7 days old wheat seedlings were determined. Quantitatively the vacuolar enzyme significantly exceeded the apoplastic one, but the specific (per unit of protein) activity of the latter was almost 2 times 
higher (Fig. 1, a). According to the IEF, the cells contained only acidic forms of chitinase with $\mathrm{pI}$ from $\sim 3.6$ to 5.1, while inside the cells - neutral and alkaline components with pI from $\sim 6.6$ to 9.3 (Fig. 1, b). The zones of chitinase activity in the gel after IEF were identified using the substrate of glycol chitin, therefore these enzymes were endochitinases.

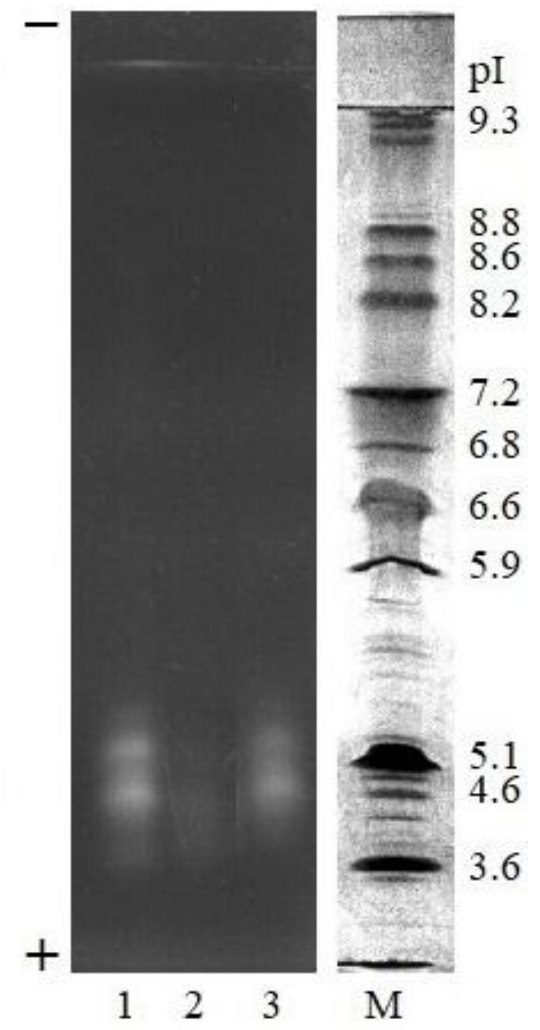

Figure-2. IEF of exochitinase (substrate 4-MUFNAG) of the wheat seedlings: 1- germinating grains, 2- roots, 3- shoots, M- pI markers

According to the mode of action on the substrate, chitinases are divided into two types - endochitinases and exochitinases. In addition, chitinolytic enzymes can exhibit the activity of $\mathrm{N}$-acetyl- $\beta$ glucosaminidase, which are referred to the exo-action chitinases. It is well known from the literature, that the endo/exo type of action largely determines the participation or degree of participation of the enzyme in the defense against pathogenic attack. To detect exochitinase in the gel after IEF we used a specific chromogenic substrate 4-methylumbelliferyl-Nacetyl-glucosaminide. From the presented electrophoregram, it follows that $\mathrm{N}$-acetyl- $\beta$ glucosaminidase of wheat seedling is represented exclusively by acidic components in the $\mathrm{pH}$ range 4.3-5.2 (Fig. 2).
Purification of chitinase with CBD substrate by affinity chromatography and determination of its isozyme composition

By their structure, chitinases are subdivided into forms containing a chitin-binding domain (mainly chitinases of class I) and those not containing this domain (classes II and III). The presence or absence of CBD is an important characteristic and plays a critical role in the display of the enzyme's antifungal properties.
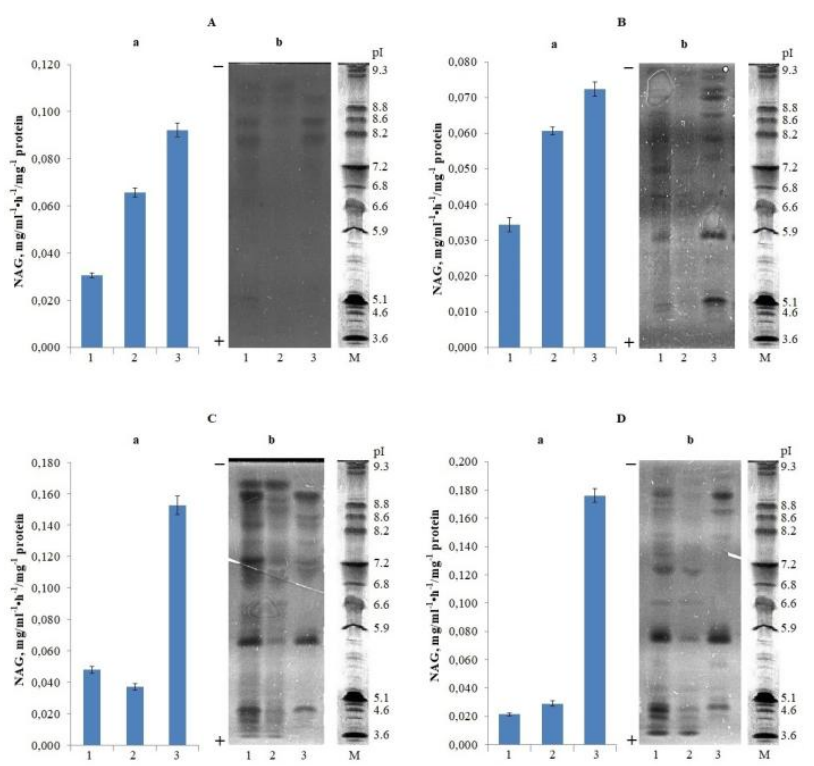

Figure-3. Activity (a) and IEF (b) of chitinases of the wheat seedlings: 1- total chitinase, 2- chitinase without CBD, 3- chitinase with CBD, M- pI markers. A-dormant grains; B-germinaiting grains; C-shoots; D-roots.

To identify and purify chitinases with CBD from various seedling organs, we used a column with insoluble chitin (chitin resin), as described above in the "Materials and Methods" section. Analysis of the distribution of chitinase activity over various organs of the seedling showed that the specific activity of the enzyme with CBD is highest in roots and shoots as compared with dormant and germinating grains (Fig. 3, a). According to the IEF data, chitinases with CBD, exhibiting specificity for the affinity sorbent, were present in the acidic, neutral and alkaline regions of spectrum (Fig. 3, b). Most isoforms of this class of chitinases had alkaline pI values $(\sim 9.3,9.0,8.6,8.2$, 8.0, 7.6). Components with $\mathrm{pI} \sim 9.1,8.8,4.0,3.6 \mathrm{did}$ not bind to the affinity sorbent, which indicated the absence of CBD in their structure, i.e. they do not belong to class I chitinases. It should be noted that the 
IEF spectrum of chitinases with CBD in vegetative organs (root and shout) and in grains as a whole is similar, and isozymes with $\mathrm{pI} \sim 9.0,8.6,7.6,5.7$ were common. However, among chitinases with CBD in germinating grain, basic isoforms prevailed in the $\mathrm{pH}$ range of $\sim 7.2-9.3$. The main (major) chitinases with and without CBD in wheat seedlings are components with $\mathrm{pI} \sim 9.0,5.7,4.6$ and 9.1, 3.6, respectively.

For greater clarity, the data on chitinases and their isoelectric points from grain and seedling organs were summarized in Table 1.

Table-1. Isoforms of chitinases with and without CBD and their isoelectric points

\begin{tabular}{|l|c|c|c|c|c|c|}
\hline \multirow{2}{*}{ Plant organ } & \multicolumn{2}{|c|}{ Chitinase without CBD } & \multicolumn{3}{c|}{ Chitinase with CBD } \\
\cline { 2 - 7 } & Basic & Neutral & Acid & Basic & Neutral & Acid \\
\hline Dormant grain & 9.1 & - & - & $\begin{array}{c}9.0,8.6, \\
8.2\end{array}$ & - & - \\
\hline $\begin{array}{l}\text { Germinated } \\
\text { grain }\end{array}$ & - & 7.0 & - & $\begin{array}{c}9.3,9.1, \\
9.0,8.6\end{array}$ & $7.6,6,9$ & $5.7,5.1$ \\
\hline Root & - & $7.0,6.6$ & $4.0,3.6$ & $9.0,8.6$ & 7.6 & $5.7,4.6$ \\
\hline Shoot & $9.1,8.8$ & - & $4.0,3.6$ & $\begin{array}{c}9.0,8.6, \\
8.4\end{array}$ & $7.6,7.2$ & $5.7,4.6$ \\
\hline
\end{tabular}

The presented data show the similarities and differences in the quantitative distribution and the presence in the IEF spectrum of chitinase isoforms with $\mathrm{CBD}$ and without $\mathrm{CBD}$ in the organs of the wheat seedlings. It should be noted that dormant and germinating grains are characterized by a high presence of chitinases with CBD (almost all components of the spectrum are adsorbed on the chitin column). Unlike grains in shoots and especially in roots, chitinases without $\mathrm{CBD}$ are significantly higher.

Determination of the molecular weight of chitinases with CBD by SDS-PAG electrophoresis

To determine the molecular weight of chitinase with CBD, small portions of extracts from resting grains and various seedling organs were bound to chitin resin and subjected to denaturing SDS-PAG electrophoresis. It was found that chitinase with CBD is represented by three proteins with molecular weights of about 33, 35, and $56 \mathrm{kDa}$ (Fig. 4, a). Renaturation of the enzyme after SDS-PAG electrophoresis and staining of the gel for chitinase activity confirmed the data obtained on the component composition and molecular weight of chitinase bound by an insoluble polymer (Fig. 4, b).

An important characteristic of a protein is the presence or absence of a carbohydrate residue in its structure. As it is known, glycosylation gives a protein a number of properties, for example, increased resistance to proteolysis and high temperature, promotes its targeted transport, etc. To determine whether chitinase is a glycoprotein, SDS-PAG electrophoresis was performed followed by specific staining of PAG for the presence of a carbohydrate residue. As a result, it was found that chitinase bound by chitin does not give a positive reaction, i.e. not glycosylated (Fig. 4, c).

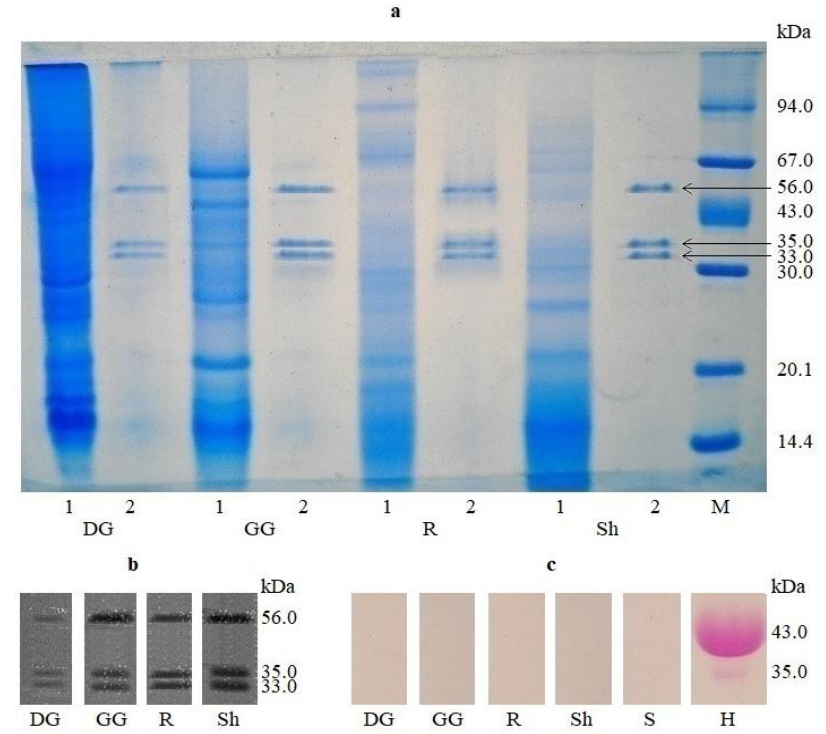

Figure-4. SDS-PAGE electrophoresis of chitinases of the wheat seedlings: 1- total chitinase, 2- chitinase with CBD, M- M.w. markers (a), SDS-PAGE electrophoresis with renaturation (substrate glycol chitin) (b) and SDSPAGE electrophoresis for glycoprotein staining (c): DGdormant grains, GG-germinaiting grains, R-roots, Shshoots, S-negative control (soybean trypsin inhibitor), H-positive control (horseradish peroxidase)

Thermal stability of chitinases in wheat seedlings The thermal stability of chitinase and its individual components has been studied. For this, the enzyme extract from the shoots was heated for 10 minutes at temperatures of $60,63,66$ and $69^{\circ} \mathrm{C}$. After heating, the samples were rapidly cooled and centrifuged to remove denatured proteins. The control was an unheated enzyme. Analysis of activity and native IEF showed the presence of relatively thermostable and thermolabile chitinase components. At $60^{\circ} \mathrm{C}$ heating the sample for 10 minutes, the chitinase activity was slightly $(5 \%)$ higher than in the control. With further heating, the enzyme activity decreased by more than $90 \%$ (Fig. 5, a). Almost all chitinases, with an exception of one main component with pI $\sim 8.6$, withstood heating to $60^{\circ} \mathrm{C}$ (Fig. 5, b). 


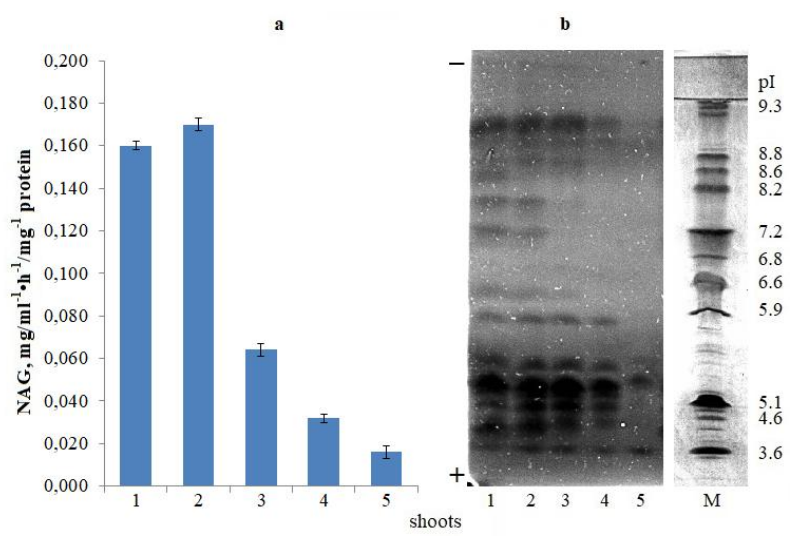

Figure-5. Activity (a) and IEF (b) of chitinase of the wheat shoots: $1-30^{\circ} \mathrm{C}$ (control), 2- $60^{\circ} \mathrm{C}, 3-63^{\circ} \mathrm{C}$, 4- $66^{\circ} \mathrm{C}, 5-69^{\circ} \mathrm{C}, \mathrm{M}-\mathrm{pI}$ markers

Heating at $63^{\circ} \mathrm{C}$ led to a disappearance from the spectrum of two weakly basic chitinases with $\mathrm{pI} \sim 7.2$ and 8.0, and at $66^{\circ} \mathrm{C}$ - of one neutral component with $\mathrm{pI} \sim 6.6$, and basic component with $\mathrm{pI} \sim 8$.6. Only two components: acidic with pI $\sim 3.6$ and weakly acidic with pI $\sim 5.4$ withstood a temperature of $69^{\circ} \mathrm{C}$.

\section{Discussion}

A review of the literature has shown that among cereals, the chitinase complex in wheat remains one of the poorly studied. Data on the physicochemical properties, isoenzyme composition, cellular localization, and organ specificity of wheat chitinases are scarce. There is no information on the identification of individual components of the electrophoretic spectrum, their belonging to one or another class of chitinases. Meantime, this knowledge is necessary for a better understanding of the functioning of the wheat chitinase system in the normal and stress conditions, as well as for assessing the defense potential against pathogens. Molecular weight, isoelectric point, thermal stability, kinetic parameters, the presence or absence of a chitin binding domain, and cell localization are very important characteristics for the classification of chitinases.

For display of the physicochemical properties and functional features of chitinases, an important factor is their cellular localization. Our study revealed a strong distribution of individual chitinases in the shoots of wheat seedlings: basic and neutral isoforms are concentrated inside the cell (vacuolar enzymes), and acidic isoforms are concentrated outside the cell in the extracellular fluid (apoplastic enzymes). This is in good agreement with the available literature data on the localization of different isoforms of chitinases in certain other plant species. Native IEF analysis of chitinases showed the presence of one component with $\mathrm{pI} \sim 4.3$ in the apoplast, and the rest with $\mathrm{pI} \sim 9.0,8.2$ and 6.6 in the vacuole. All of these enzymes are endochitinases, since they hydrolyze polymeric chitin. In addition to endochitinases, $\mathrm{N}$-acetyl- $\beta$ glucosaminidase, which belongs to exochitinases, was also identified among the chitinolytic enzymes of wheat seedlings. This enzyme was represented by 2-3 exclusively acidic proteins with a $\mathrm{pI}$ in the range from $\sim 4.3$ to 5.2 .

The differences in the location of chitinases with different isoelectric points are not accidental and depend on the $\mathrm{pH}$ within each compartment of the secretory pathway. For example, the $\mathrm{pH}$ of the cytosol is 7.3 , the endoplasmic reticulum is 7.1 , the Golgi apparatus is 6.3 , the vacuole is 5.2 , while in the peroxisomes and apoplast it is 8.2 , and the $\mathrm{pH}$ of the apoplast is not stable and can increase in response to salt stress, drought, and also when interacting with pathogens (Shen et al., 2013; Geilfus, 2017; Savchenko et al., 2019). The same patterns in the localization of acidic and alkaline isoforms are also typical for some other enzymes, for example, $\beta-1,3-$ glucanase, protease, peroxidase, superoxide dismutase (Ignacio et al., 2015; Maksimović et al., 2019).

In the present study, a high degree of heterogeneity of chitinases in wheat seedlings with more than 10 components located in a wide $\mathrm{pH}$ range from $\sim 3.6$ to 9.3 was established using IEF in a gradient of ampholines $\mathrm{pH} 3-10$. According to the data presented in a large review (Malik, 2019), purified basic chitinases of arabidopsis, barley, beans, peas, and some other species had a pI of around 9.0, neutral chitinases in beans and cotton were close to 7.0, and acidic chitinases from beans, peas, ficus and tomatoes were about 4.0. In our study, we found a great similarity in the IEF spectra of chitinase from germinating grains, roots, and shoots of wheat seedlings in terms of the set of components and their distribution in the gel. On the other hand, the resting grains contained a small amount of isozymes (about 5), which located mainly in the alkaline $\mathrm{pH}$ range. In germinating grains, the component composition of chitinases was much richer, however, in the acidic region of the spectrum, there was only one isozyme with $\mathrm{pI} \sim 5.1$. High polymorphism of the enzyme is typical for both germinating grains and vegetative organs.

Chitinases of class I play a very important role in plant 
protection against fungal pathogens, since they have a direct antifungal effect due to the presence (in addition to the catalytic) chitin binding domain. CBD provides binding of the enzyme to the chitinous membrane of the fungus, lysis of the polymer, and suppression or death of the pathogen. A detailed study of the structure of class I chitinase from Vigna unguiculata, purified by affinity chromatography, showed the content of 8 cysteine residues in the chitin-binding domain at the same positions as in hevein. Analysis of the crystallographic model and molecular calculations of coupling using chitooligosaccharides revealed the presence of residues involved in sugar binding and catalysis, as well as a possible mechanism of antifungal action (Landim et al., 2017). Recently, researchers have paid close attention to the identification, study of the properties and application of class I chitinases and their genes to increase the resistance of agricultural plants to phytopathogens (Toufiq et al., 2018; Bartholomew et al., 2019).

For the purification of chitinases with CBD, a substrate affinity precipitation by batch method or chromatography on a colloidal or regenerated chitin matrix is usually used. In our work, a chitin resin column was used as a specific sorbent, the effectiveness of which has been shown in other studies (Singh et al., 2007; Sørensen et al., 2010). Using this sorbent, chitinases from grain and wheat seedling organs were separated into isoforms with and without CBD. Both forms of chitinase were identified in the IEF spectrum; isoforms with CBD from shoots had $\mathrm{pI}$ values around $\sim 9.0,8.6,8.4,7.6,7.2,5.7$ and 4.6. In many ways, similar spectra of this enzyme were observed in roots and germinating grains with insignificant differences in individual components. In particular, germinating grain is characterized by the presence of additional strongly basic isozymes with $\mathrm{pI}$ $\sim 9.3$ and 9.2. Acid chitinases, except for components with $\mathrm{pI} \sim 4.6$ and 5.7, did not bind to the affinity sorbent, i.e., they did not contain CBD in their structure. The data obtained indicate a noticeable predominance of isoforms with CBD in the chitinase complex in wheat, which is generally typical for plants.

Chitinases are a very diverse group of enzymes. They vary in activity, temperature and $\mathrm{pH}$ optima, and in size. Their molecular weight usually ranges from $\sim 20$ to $120 \mathrm{kDa}$, whereas the most bacteria has a range of $\sim 20-60 \mathrm{kDa}$, and in plants this value is $\sim 25-40 \mathrm{kDa}$ (Kisiel and Jęckowska, 2019). In our work, using SDS-PAG electrophoresis, the M.w. for chitinases with CBD of wheat seedlings was determined and it corresponded to $\sim 33,35$ and $56 \mathrm{kDa}$. The sizes of the first two proteins are well within the indicated limits for plant chitinases. The third protein was slightly larger than the usual sizes for plant chitinases (56 $\mathrm{kDa}$ ), however, isoforms with $\sim 20 \mathrm{kDa}$ or $\geq 40 \mathrm{kDa}$ were also previously described (Chang et al., 2014). When studying the enzyme activity in tetra- and hexaploid wheat genotypes, gel detection analysis revealed up to four fractions ( $\sim 20,30,42$, and $95 \mathrm{kDa})$ of proteins with chitinase activity in relation to the long chain of polymers (Moravčíková et al., 2017). In the gel after SDS-PAG electrophoresis of chitinases from triticale seedlings, there were five separate protein bands with low $(18,23,26$, and $33 \mathrm{kDa})$ and relatively high M.w. (51 and $55 \mathrm{kDa}$ ) (Zur et al., 2013). Most of the low M.w. chitinases exhibited antifungal activity in vitro as well as in vivo, while high M.w. isoforms were involved in protection from abiotic (cold) stress. A number of studies have investigated the structure and enzymatic properties of chitinases with CBD from other cereals. The molecular weight of the enzyme from rye and rice was $\sim 26 \mathrm{kDa}$, and from barley and corn $\sim 32 \mathrm{kDa}$ (Ohnuma et al., 2012; Tanaka et al., 2017; Toufiq et al., 2018; Dowd et al., 2018). All these chitinases belong to class I of family 19 glycosyl hydrolases (GH19).

Among plant chitinases both glycosylated forms, i.e. enzymes having carbohydrate residues in the structure and not glycosylated forms are found. As it is known, the carbohydrate component gives the protein molecule greater resistance, for example, to elevated temperature or the action of proteases. The multifunctional enzyme ICChI with the activity of chitinase/lysozyme/exochitinase which is glycosylated (14-15\%) and has M.w. $35 \mathrm{kDa}$ and pI 5.3 was purified from the latex of Ipomea carnea. The enzyme is stable at $80^{\circ} \mathrm{C}$, and the glycoprotein nature of the protein may well be a factor of high thermal stability (Patel et al., 2009). Glycosylation is usually performed by enzymes designed for secretion outside the cells, but vacuolar class I chitinase in tobacco leaves is not glycosylated. As shown in this work, chitinases with CBD from wheat seedlings did not give a positive reaction with Schiff's reagent, i.e. do not contain carbohydrate residues. This chitinase is mainly represented by intracellular basic and neutral isoforms. There is very little information in the literature on glycosylated chitinases in plants, but these secreted enzymes are better described in various 
animals and microorganisms, which are characterized by a serine/threonine-rich glycosylated domain (Hamid et al., 2013; Le and Yang, 2019).

Plants do not contain very heat-labile chitinases, but highly thermostable enzymes have been isolated from pomegranate, which remain active up to $65^{\circ} \mathrm{C}$ for several hours, enzymes from beans retained $70 \%$ of the initial activity at $70^{\circ} \mathrm{C}$ after 60 minutes of exposure, whereas chitinases from garden bean remain stable only up to $60^{\circ} \mathrm{C}$ (Kopparapu et al., 2011; Sharma and Hooda, 2018; Wang et al., 2012). Our study showed that the components of chitinase from wheat seedlings have different sensitivity to elevated temperature. The acidic components exhibited the highest thermal stability, three of which with $\mathrm{pI} \sim 3.6$, 5.1 , and 5.4 withstood heating at $69^{\circ} \mathrm{C}$ for 10 minutes. Neutral and basic isoforms are more thermolabile and lose activity at $66^{\circ} \mathrm{C}$. An interesting fact is a slight increase in the activity of chitinase relative to the control after heating to $60^{\circ} \mathrm{C}$, which is probably associated with a disappearing of inhibitory proteins. In general, in comparison with other plant species, wheat has a moderate thermal stability of chitinase, especially its acidic isoforms.

The data obtained make it possible to classify wheat seedling chitinases, which bind to insoluble chitin, to class I, since they have CBD in their structure. These enzymes are represented by basic, neutral and acidic isoforms. Their molecular weight is greater than 30 $\mathrm{kDa}$ and they are not glycosylated. Chitinases not bound by chitin do not contain CBD and are classified as class II or possibly class III, which are also found in cereals. These isoforms are represented by isozymes with different $\mathrm{pI} \sim 9.1,7.0,4.0$, and 3.6. Chitinases of class II are mainly acidic apoplastic proteins, for example, in sweet potatoes, the enzyme has a M.w. $26.3 \mathrm{kDa}$ and pI 5.0 (Liu et al., 2020). Extracellular acidic chitinases of class III with bifunctional lysozyme/chitinase activity have been found, for example, in hevea, cucumber, and arabidopsis (Malik, 2019). Among the chitinolytic enzymes of wheat seedlings, N-acetylglucosaminidase was also identified, which is represented by 2-3 exclusively acidic proteins with $\mathrm{pI}$ ranging from $\sim 4.3$ to 5.2.

\section{Conclusion}

The data obtained in this study show that chitinase in wheat seedlings is represented by multiple molecular forms. Among them, intra- and extracellular enzymes were found, as well as isoforms with a chitin-binding domain and without CBD. Their isoelectric focusing and SDS-PAG electrophoresis pattern was established. The results expand knowledge about the wheat chitinase complex and can be useful in the search and identification of enzymes (and individual isozymes) as markers of resistance to fungal pathogens.

\section{Acknowledgement}

Authors acknowledge the financial support for this study by Ministry of Education and Sciences of the Republic of Kazakhstan (Grant No. AP05133823).

Disclaimer: None.

Conflict of Interest: None.

Source of Funding: This study was conducted with financial support from Ministry of Education and Sciences of the Republic of Kazakhstan (Grant No. AP05133823).

\section{References}

Aleandri MP, Magro P and Chilosi G, 2008. Influence of environmental $\mathrm{pH}$ modulation on efficiency of apoplastic PR proteins during Fusarium culmorum wheat seedling interaction. Plant Pathol. 57(6): 1017-1025.

Anand A, Lei Zh, Sumner LW, Mysore KS, Arakane Y, Bockus WW and Muthukrishnan S, 2004. Apoplastic extracts from a transgenic wheat line exhibiting lesion-mimic phenotype have multiple pathogenesis-related proteins that are antifungal. Mol. Plant-Microbe Interact. 17(12): 1306-1317.

Bartholomew ES, Black K, Feng Zh, Liu W, Shan N, Zhang X, Wu L, Bailey L, Zhu N, Qi C, Ren H and Liu X, 2019. Comprehensive analysis of the chitinase gene family in cucumber (Cucumis sativus L.): from gene identification and evolution to expression in response to Fusarium oxysporum. Int. J. Mol. Sci. 20(21): 1-21.

Chang YM, Chen LC, Wang HY, Chiang CL, Chang CT and Chung YC, 2014. Characterization of an acidic chitinase from seeds of black soybean (Glycine max (L) Merr Tainan No. 3). PLoS One. 9(12): 1-15.

Dowd PF, Naumann TA, Price NPJ and Johnson ET, 2018. Identification of a maize (Zea mays) chitinase allele sequence suitable for a role in ear rot fungal resistance. Agri Gene. 7: 15-22.

Dušková J, Tishchenko G, Ponomareva E, Šimůnek J, Koppová I, Skálová T, Štěpánková A, Hašek J and Dohnálek J, 2011. Chitinolytic enzymes from 
bacterium inhabiting human gastrointestinal tract critical parameters of protein isolation from anaerobic culture. Acta Biochim. Pol. 58(2): 261263.

Ebrahim S, Usha K and Singh B, 2011. Pathogenesis related (PR) proteins in plant defense mechanism, pp. 1043-1054. In A. Méndez-Vilas (ed.), Science against microbial pathogens: communicating current research and technological advances, vol. 2. Formatex Research Center, Badajoz, Spain.

Fink W, Liefland M and Mendgen K, 1988. Chitinases and $\beta$-1,3-glucanases in the apoplastic compartment of oat leaves (Avena sativa L.). Plant Physiol. 88(2): 270-275.

Geilfus CM, 2017. The $\mathrm{pH}$ of the apoplast: dynamic factor with functional impact under stress. Mol. Plant.10(11): 1371-1386.

Gijzen M, Kuflu K, Qutob D and Chernys JT, 2001. A class I chitinase from soybean seed coat. J. Exp. Bot. 52(365): 2283-2289.

Grover A, 2012. Plant chitinases: Genetic diversity and physiological roles. Crit. Rev. Plant Sci. 31(1): 5773.

Hamid R, Khan MA, Ahmad M, Ahmad MM, Abdin MZ, Musarrat J and Javed S, 2013. Chitinases: an update. J. Pharm. Bioallied Sci. 5(1): 21-29.

Ignacio IF, Carmela AA and Blondy CC, 2015. Recovery of active pathogenesis-related enzymes from the apoplast of Musa acuminata infected by Mycosphaerella fijiensis. Afr. J. Biotechnol. 14(23): 1970-1981.

Iqbal RK and Anwar FN, 2019. Chitinases potential as bio-control. Biomed. J. Sci. Tech. Res. 14(5): 1099411001.

Kaczmarek MB, Struszczyk-Swita K, Li X, SzczęsnaAntczak M and Daroch M, 2019. Enzymatic modifications of chitin, chitosan, and chitooligosaccharides. Front. Bioeng. Biotechnol. 7: 1-26.

Kasprzewska A, 2003. Plant chitinases-regulation and function Cell. Mol. Biol. Lett. 8(3): 809-824.

Kisiel A and Jęckowska K, 2019. Chitinases as the key to the interaction between plants and microorganisms. Postep. Mikrobiol. 58(3): 317-327.

Kopparapu NK, Liu Z, Yan Q, Jiang Z and Zhang S, 2011. A novel thermostable chitinase (PJC) from pomegranate (Punica granatum) juice. Food Chem. 127(4): 1569-1575.

Kumar M, Brar A, Yadav M, Chawade A, Vivekanand V and Pareek N, 2018. Chitinases - potential candidates for enhanced plant resistance towards fungal pathogens. Agric. 8(7): 1-12.

Laemmli UK, 1970. Cleavage of structural proteins during the assembly of the head of bacteriophage T4. Nature. 227(5259): 680-685.

Landim P, Correia TO, Silva F, Nepomuceno DR, Costa H, Pereira HM, Lobo M, Moreno F, Brandão-Neto J, Medeiros SC, Vasconcelos IM, Oliveira J, Sousa BL, Barroso-Neto IL, Freire VN, Carvalho C, Monteiro-Moreira A and Grangeiro TB, 2017. Production in Pichia pastoris, antifungal activity and crystal structure of a class I chitinase from cowpea (Vigna unguiculata): insights into sugar binding mode and hydrolytic action. Biochim. 135: 89-103.

Le B and Yang SH, 2019. Microbial chitinases: properties, current state and biotechnological applications. World J. Microbiol. Biotechnol. 35(9): 1-12.

Liu M, Gong Y, Sun H, Zhang J, Zhang L, Sun J, Han Y, Huang J, Wu Q, Zhang C and Li Z, 2020. Characterization of a novel chitinase from sweet potato and its fungicidal effect against Ceratocystis fimbriata. J. Agric. Food Chem. 68(29): 7591-7600.

Lowry OH, Rosenbrough NJ, Farr AL and Randall RJ, 1951. Protein measurement with the folin. J. Biol. Chem. 193(1): 265-275.

Maksimović JD, Mojović M, Vučinić Ž, and Maksimović V, 2019. Longitudinal distribution of apoplastic antioxidative components in maize root. Biol. Serb. 41(2): 83-89.

Malik AP, 2019. Purification and properties of plant chitinases: a review. J. Food Biochem. 43(3): 1-11.

Molano J, Polacheck I, Duran A and Cabib E, 1979. An endochitinase from wheat germ: activity on nascent and preformed chitin. J. Biol. Chem. 254(11): 49014907.

Mohammadi M, Roohparvar R and Torabi M, 2002. Induced chitinase activity in resistant wheat leaves inoculated with an incompatible race of Puccinia striiformis f. sp. tritici, the causal agent of yellow rust disease. Mycopathol. 154(3), 119-126.

Moravčíková J, Ujvariová N, Žur I, Gálová Z, Gregorová Z, Zimová M, Boszorádová E and Matušíková I, 2017. Chitinase activities in wheat and its relative species. Agr. (Pol'nohospodárstvo). 63(1): 14-22.

Ohnuma T, Numata T, Osawa T, Inanaga H, Okazaki Y, Shinya S, Kondo K, Fukuda T and Fukamizo T, 2012. Crystal structure and chitin oligosaccharidebinding mode of a 'loopful' family GH19 chitinase from rye, Secale cereale, seeds. FEBS J. 279(19): 3639-3651.

O'Leary BM, Rico A, McCraw S, Fones HN and Preston GM, 2014. The infiltration-centrifugation technique for extraction of apoplastic fluid from plant leaves using Phaseolus vulgaris as an example. J. Vis. Exp. (94): 1-8. 
Oyeleye A and Normi YM, 2018. Chitinase: diversity, limitations, and trends in engineering for suitable applications. Biosci. Rep. 38(4): 1-21.

Pan SQ, Ye XS and Kuć J, 1989. Direct detection of beta1,3-glucanase isozymes on polyacrylamide electrophoresis and isoelectrofocusing gels. Anal. Biochem. 182(1): 136-140.

Patel AK, Singh VK, Yadav RP, Moir AJG and Jagannadham MV, 2009. ICChI, a glycosylated chitinase from the latex of Ipomoea carnea. Phytochem. 70(10): 1210-1216.

Sharma P and Hooda V, 2018. Purification and analytical application of Vigna mungo chitinase for determination of total fungal load of stored cereals. Appl. Biochem. Biotechnol. 186(1): 12-26.

Rathore AS and Gupta RD, 2015. Chitinases from bacteria to human: properties, applications, and future perspectives. Enzyme Res. 2015: 1-8.

Ride JP and Barber MS, 1990. Purification and characterization of multiple forms of endochitinase from wheat leaves. Plant Sci. 71(2): 185-197.

Savchenko GE, Bachyshcha TS and Kabashnikova LF, 2019. Influence of exogenous $\beta$-1,3-glucane on the $\mathrm{pH}$ level of apoplast and cytoplasm in healthy and Bipolaris sorokiniana (sacc.) shoem. seedlings of barley ( Hordeum vulgare L.)-infected tissues. Dokl. Nats. Akad. Nauk Belarusi. 63(3): 317-324.

Sharma N, Sharma KP, Gaur RK and Gupta VK, 2011. Role of chitinase in plant defense. Asian J. Biochem. 6(1): 29-37.

Sharma V, 2013. Pathogenesis related defence functions of plant chitinases and $\beta$-1,3-glucanases. Vegetos. 26(2s): 205-218.

Shen J, Zeng Y, Zhuang X, Sun L, Yao X, Pimpl P and Jiang L, 2013. Organelle $\mathrm{pH}$ in the Arabidopsis endomembrane system. Mol. Plant. 6(5): 14191437.

Singh A, Kirubakaran SI and Sakthivel N, 2007. Heterologous expression of new antifungal chitinase from wheat. Protein Expr. Purif. 56(1): 100-109.

Sørensen HP, Madsen LS, Petersen J, Andersen JT, Hansen AM and Beck HC, 2010. Oat (Avena sativa) seed extract as an antifungal food preservative through the catalytic activity of a highly abundant class I chitinase. Appl. Biochem. Biotechnol. 160(6): 1573-1584.

Taira T, 2010. Structures and antifungal activity of plant chitinases. J. Appl. Glycosci. 57(3): 167-176.

Taira T, Ohnuma T, Yamagami T, Aso Y, Ishiguro M and Ishihara M, 2002. Antifungal activity of rye (Secale cereale) seed chitinases: the different binding manner of class I and class II chitinases to the fungal cell walls. Biosci. Biotechnol. Biochem. 66(5): 970-977.

Tanaka J, Fukamizo T and Ohnuma T, 2017. Enzymatic properties of a GH19 chitinase isolated from rice lacking a major loop structure involved in chitin binding. Glycobiol. 27(5): 477-485.

Toufiq N, Tabassum B, Bhatti MU, Khan A, Tariq M, Shahid N, Nasir IA and Husnain T, 2018. Improved antifungal activity of barley derived chitinase I gene that overexpress a $32 \mathrm{kDa}$ recombinant chitinase in Escherichia coli host. Braz. J. Microbiol. 49(2): 414-421.

Trudel J and Asselin A, 1989. Detection of chitinase activity after polyacrylamide gel electrophoresis. Anal. Biochem. 178(2): 362-366.

Wang S, Ye X, Chen J and Rao P, 2012. A novel chitinase isolated from Vicia faba and its antifungal activity. Food Res. Int. 45(1): 116-122.

Zur I, Gołebiowska G, Dubas E, Golemiec E, Matušíková I, Libantová J and Moravčíková J, 2013. $\beta$-1,3-glucanase and chitinase activities in winter triticales during cold hardening and subsequent infection by Microdochium nivale. Biologia (Poland). 68(2): 241-248.

\section{Contribution of Authors}

Khakimzhanov A: Data analysis, literature review and manuscript writing

Kuzovlev V: Designed research methodology and data collection

Abaildayev A: Data collection, statistical analysis and manuscript writing 